\title{
The level of water in the river flowing through the breeding site shapes the body condition of a lekking bird-the Great Snipe Gallinago media
}

\author{
Marta Witkowska $^{1}$ D $\cdot$ Pavel Pinchuk $^{2,4} \cdot$ Włodzimierz Meissner $^{1}$ (D) $\cdot$ Natalia Karlionova $^{3}$ (D) Zuzanna Marynkiewicz $^{1}$
}

Received: 8 June 2021 / Revised: 6 January 2022 / Accepted: 19 January 2022 / Published online: 7 February 2022

(c) The Author(s) 2022

\begin{abstract}
The display of lekking Great Snipe males is an energetically demanding activity and therefore, access to the rich feeding sites in the proximity of their leks is essential. During the breeding season, Great Snipes mostly prey on earthworms, whose availability is affected by moisture and penetrability of the soil. In this study, we investigated the relation between the body condition of displaying Great Snipe males and the water level of the river flowing through their breeding grounds, which can affect soil characteristics. We found that the body condition of males decreased over the course of the lekking period in May, showing the great energetic expenditure of their advertising display in courtship. The high water level in the river resulted in the increase in body condition of birds, probably due to improved prey availability, as earthworms moved closer to the ground surface in search of optimal conditions. Further rise in the water level caused flooding of the meadow and a decrease in the body condition of lekking Great Snipes, possibly because of the deterioration of feeding condition, as earthworms tend to leave flooded areas. Moreover, as the flooded area enlarged, the floodplain became inaccessible for foraging Great Snipes, due to their relatively short legs restricting them from wading in deep water. Our results show that for the lowland leks of the Great Snipe to be preserved it is advisable to allow for the natural water level fluctuations in the river shaping the hydrological conditions of the floodplains.
\end{abstract}

Keywords Communal courtship $\cdot$ Body mass $\cdot$ Floodplains $\cdot$ Wet meadow $\cdot$ Wader

\section{Zusammenfassung}

Der Wasserstand eines Flusses durch das Brutareal beeinflusst die physische Verfassung balzender Doppelschnepfen Gallinago media

Das Balzen der Doppelschnepfe ist eine energetisch anspruchsvolle Tätigkeit, weshalb die Verfügbarkeit naher, ergiebiger Futterplätze von wesentlicher Bedeutung ist. Während der Brutzeit ernähren sich die Doppelschnepfen hauptsächlich von Regenwürmern, deren Verfügbarkeit wiederum von der Feuchte und Durchlässigkeit des Bodens abhängt. In dieser Studie untersuchten wir den Zusammenhang zwischen der physischen Verfassung balzender Doppelschnepfenmännchen und dem Wasserstand des Flusses, der durch ihr Brutgebiet fließt und möglicherweise die Bodenbeschaffenheit beeinflusst. Wir stellten fest, dass die physische Verfassung der Männchen im Laufe der Balzzeit im Mai abnahm, was auf den hohen Energieaufwand für ihre Balz-Aktivitäten hinweist. Ein hoher Wasserstand des Flusses führte zu einer Verbesserung der physischen Verfassung der Vögel, was wahrscheinlich an der besseren Verfügbarkeit von Beute lag, da dann die Regenwürmer auf der Suche nach besseren Bedingungen näher an die Bodenoberfläche kommen. Ein weiterer Anstieg des Wasserspiegels

Communicated by F. Bairlein.

Marta Witkowska

marta.witkowskaa@gmail.com

1 Ornithology Unit, Department of Vertebrate Ecology and Zoology, Faculty of Biology, University of Gdańsk, Wita Stwosza 59, 80-308 Gdańsk, Poland
2 APB BirdLife Belarus, Minsk, Belarus

3 Scientific and Practical Center for Biological Resources, National Academy of Sciences of Belarus, Minsk, Belarus

4 National Park "Pripyatsky", Gomel, Belarus 
führte zur Überflutung der Wiese und zu einer Verschlechterung der physischen Verfassung der balzenden Doppelschnepfen, möglicherweise wegen der Verschlechterung der Nahrungsbedingungen, weil Regenwürmer dazu neigen, überflutete Gebiete zu verlassen. Mit der Vergrößerung des Überschwemmungsgebiets und steigendem Wasserspiegel wurde das Gebiet außerdem für die Doppelschnepfen unzugänglich, da sie aufgrund ihrer relativ kurzen Beine nicht in tieferem Wasser waten können. Unsere Ergebnisse zeigen, dass es für den Erhalt tiefer liegender Balzplätze von Doppelschnepfen ratsam ist, die natürlichen Wasserstandsschwankungen von Flüssen, die die hydrologischen Bedingungen von Hochwassergebieten prägen, zuzulassen.

\section{Introduction}

The lekking behaviour is relatively rare among species, yet it is present in a great number of taxa, e.g., insects, amphibians, mammals and birds (Höglund and Alatalo 1995; Fiske et al. 1998). Lekking is a communal, competitive courtship display of males aiming to draw females to the lekking site. Females choose a mate among displaying males based on their performance along with secondary sexual traits and then engage in courtship. When it comes to breeding performance, lekking males invest resources mainly in their secondary sexual traits, as they do not participate in parental care (Höglund and Alatalo 1995). A number of those traits, ranging from the quality of ornaments to the intensity of the display are related to the body condition of an individual. Generally, males with higher body condition, which allows for a higher amount of energy expenditure on lekking, are more attractive to females visiting the lekking site (Carranza and Hidalgo de Trucios 1993; Andersson 1994; Morales et al. 2003; Sardà-Palomera et al. 2011; Yang et al. 2013; Jiguet and Bretagnolle 2014). The evolutionary rule is that females rely on the condition-dependent traits as indicators of the general quality of a mate, not only in terms of the mating performance but also other biological aspects. This allows for an indirect increase in the fitness of the female, as traits of a high-quality male may be inherited by a female's offspring (Höglund and Alatalo 1995; Ryder et al. 2010).

The Great Snipe Gallinago media is a lekking wader species, whose eastern, lowland population occurs in grassland habitats, such as pastures, marshes, and floodplain meadows of river valleys (Lemnell 1978; Cramp and Simmons 1983). Among a number of the secondary sexual traits hypothesised to influence the attractiveness of a displaying male, the high rate of the display performance was proved to be favoured by females (Höglund and Lundberg 1987; Höglund et al. 1992; Sæther et al. 2000; Ekblom et al. 2004). Such performance is energetically costly for displaying males, as their daily energy expenditure during a breeding period reaches four times the basal metabolic rate, which is considered to be almost the maximum sustainable work rate for birds. Great Snipe males lose approximately $5 \%$ of their body mass during a single night of active lekking (Höglund et al. 1992). Therefore, males must rely on abundant prey available at feeding sites on their breeding grounds, as breeding display constrains the replenishment of energetic resources by foraging during the day. The location of the Great Snipe leks is determined by the proximity of such rich feeding sites, especially with easily accessible and abundant earthworms Lumbricidae that compose $90 \%$ of the diet in this species (Løfaldli et al. 1992; Kålås et al. 1997; Korniluk et al. 2020). Hence, it is possible, that the availability of high quality food such as earthworms determines the body condition of lekking birds.

Terrestrial earthworms constitute the majority of soil animal biomass in grasslands (Zorn et al. 2005; Hamer et al. 2006) and their availability often determines the richness of the feeding sites for birds (Green et al. 1990; Vickery et al. 2001; Atkinson et al. 2004; Davis et al. 2006). Their vertical distribution in the soil is mainly determined by the soil moisture (Rundgren 1975; Jiménez and Decaëns 2000), as earthworms require the optimal moisture content for maintaining their body hydrostatic pressure and respiration (Bohlen and Edwards 1995). Although the preference for soil moisture is species-specific and may differ with the type of inhabited soil, in most studies the greatest abundance of earthworms was reported at approximately $30 \%$ soil moisture content (Grant 1955; Berry and Jordan 2001; Wever et al. 2001; Onrust et al. 2019). This indicates that optimal living conditions for earthworms is neither too dry nor too moist soil and many species of grassland earthworms abandon flooded soil (Plum and Filser 2005; Zorn et al. 2005), even though laboratory studies have shown their ability to survive long periods (14-23 weeks) immersed in the water (Roots 1956; Zorn et al. 2008). The rising level of groundwater during the flooding events causes earthworms to migrate vertically to the soil layers with sufficient oxygen and moisture content (Mather and Christensen 1988; Onrust et al. 2019). Such conditions are favourable to vertebrate earthworms' predators such as gulls, thrushes, and waders, as the accessibility of prey increases with earthworms accumulating in the top layer of the soil (Macdonald 1983; Verhulst et al. 2007; Coulson and Coulson 2008). Hence, the eastern population of the Great Snipe which accounts for the majority of the global population of this species, occupies open grassland habitats, such as floodplains and wet meadows (Kålås 2004). The hydrological conditions on these floodplain meadows are shaped by the water level in the nearby river, which can indirectly affect the quality of feeding sites (Davis et al. 
2006). Indeed, floodplain meadows are one of the world's most biologically productive areas (Ward et al. 1999; Tockner and Stanford 2002), that provide optimal feeding conditions for birds during the breeding season and enable refuelling, as they function as a stopover site for migrating birds (Verhulst et al. 2007; Rhymer et al. 2010; Pinchuk and Karlionova 2011), due to the high biomass of soil invertebrates, including earthworms (Zorn et al. 2005; Hamer et al. 2006).

We aimed to investigate the influence of the water level on the breeding site on the body condition of lekking Great Snipe males. We hypothesised that the water level in the Pripyat River flowing through the breeding site of the Great Snipe might have an indirect influence on the body condition of lekking males by affecting the soil hydrological conditions and therefore determining the availability of their prey. It is possible, that with the rise of the level of water in the river hydrological conditions of the soil in the proximate meadow changes towards higher moisture content, which can force the earthworms to move closer to the surface of the ground. This would make them more accessible for foraging Great Snipes which could result in an increase of the body condition of birds.

\section{Materials and methods}

\section{Fieldwork}

We collected the data in two closely located Great Snipe leks in the floodplain meadows of the Pripyat River near Turov, Gomel Region, Belarus ( $\left.52^{\circ} 05^{\prime} \mathrm{N}, 27^{\circ} 46^{\prime} \mathrm{E}\right)$ for 20 consecutive years since 2001. In different years up to 70 males stayed in both lekking sites. Birds were captured in mist-nets in the night. To minimize the disturbance of lekking birds, capture events on a given lek did not last longer than $4 \mathrm{~h}$ and were separated by a minimum 5-day break. The lek of the Great Snipe starts at the end of April and may last until the end of July (Lemnell 1978; Cramp and Simmons 1983). At the studied site, birds arrived around mid-April and stayed there until the end of June (authors' unpublished data). The exact duration of the lekking period may vary between years and at its early and late stages, it may overlap with other life events of the annual cycle, such as fattening for autumn migration (Lemnell 1978). The floodplain meadows of the middle Pripyat River are an important stopover site for the wildfowl and waders during spring migration (Meissner et al. 2011; Pinchuk and Karlionova 2011; Pinchuk et al. 2016) and some Great Snipes may use this area as a stopover site. Moreover, Great Snipes start moult of primary feathers on their breeding grounds at the beginning of June (Cramp and Simmons 1983; Debayle et al. 2017). The earliest start of moult in the studied population was recorded on the 6th of June (authors' unpublished data). Consequently, we included into the analysis only data collected in May when birds have already established their leks, and moult and preparation for southward migration has not yet started.

The capture hour was noted of each individual. Since birds were captured during the whole month and the length of the night differs between the 1st of May (approximately $9 \mathrm{~h}$ of night) and the $31 \mathrm{st}$ of May (approximately $7.5 \mathrm{~h}$ of night), we defined the time of the capture as the time after the sunset on a given date with accuracy to the nearest half an hour. All birds were weighed with an electronic balance to the nearest $0.1 \mathrm{~g}$ and the following measurements were taken: total head length, bill length, nostril length, tarsus length; all these were measured with callipers to the nearest $0.1 \mathrm{~mm}$. Moreover, wing length and tarsus plus toe length were measured with a ruler to the nearest $1 \mathrm{~mm}$ (Busse and Meissner 2015). The sex of an individual was identified based on bill measurements according to Höglund et al. (1990). Only males were included in further analyses. Each year the sample size ranged from 3 to 40 individuals, with a total number of 369 male Great Snipes captured and measured during 2001-2020 (additional information on sample size is given in Online Resource 1).

\section{Body condition}

The most common approach in studies is to identify individual's body condition as a measure of its state of nutrition and gathered energetic resources, that can be described as indices correcting for the structural size of an individual or as an uncorrected body mass (Labocha \& Hayes 2012; Labocha et al. 2014). A preliminary analysis showed that using a body condition index - the scaled mass index (Peig and Green (2009), showed similar results as uncorrected body mass, as it did not remove much noise from the data (Online Resources 1). Moreover, as analyses of uncorrected body mass operates on units of mass, it provides results that are easily comparable between different studies. Therefore, we used the uncorrected body mass of each male Great Snipe as an indicator of body condition based on the amount of energetic resources of an individual.

\section{Hydrological data}

Levels of water in the Pripyat River were collected for each day of May at the gauging station in Chernichi, i.e., approximately $3.5 \mathrm{kms}$ from the Great Snipe leks. This data were available for 16 years out of the 20 -year study period. We analysed data on 236 individuals, for which the data on their body mass and water level at the breeding site were available (information on sample size and between year variation is available in Online Resources 1). To investigate the influence of the water level on the body condition of male Great Snipes, we took into the account three water levels defined 
by different periods in which they were measured: (1) the water level on the day of capture, (2) the water level averaged over 5 days preceding the day of the capture and (3) the water level averaged over 14 days preceding the day of the capture. The flooding of the meadow at the studied area started when the water level reached approximately $440 \mathrm{~cm}$. When the water level was about $520 \mathrm{~cm}$, the meadow was almost completely flooded.

We used the 'rtrim' package in R (Bogaart et al. 2020) to describe the trend in the water level in the Pripyat River. For the TRIM model, we took into account daily water levels reported in 14 days preceding the date of each capture as this model requires long data series. We categorized the water level trend, based on an overall slope computed by the TRIM model, into two categories: increasing and decreasing water level. In three cases the water level was identified as stable. We decided to exclude the data collected over those capture events from further analysis, as the sample size of captured birds was too low and stable water level in rivers is rare during spring (Rawlins et al. 2009).

\section{Statistical analysis}

The body mass of lekking Great Snipe males was previously shown to decrease over a single night of lekking (Höglund et al. 1992). Therefore, we used data collected only in the first part of the night, up to $2.5 \mathrm{~h}$ hours after the time of the sunset, when we observed the nondecreasing body mass of birds (Fig. 1S) (additional information is given in Online Resource 1).

Generalized Linear Model (GLM) (McCullagh and Nelder 1989) with a log link function and normal error distribution was used to determine, whether the sampling date in the season (continuous, explanatory variable) influenced the body mass of male Great Snipes (continuous, response variable). The sampling date in the season was defined as the number of a day in May with the 1st of May being the 1st day of the season.

A preliminary analysis showed that the relationship between the body mass of male Great Snipes and the water level in the Pripyat River was not linear. Therefore, we applied the Generalized Additive Model (GAM), which is an extension of the Generalized Linear Model (GLM), widely used for analysing non-linear relations, in which the variable may be expanded as smooth functions of covariates (Hastie and Tibshirani 1986). With GAM we modelled the body mass (continuous, response variable) as a function of the water level (continuous, smoothing function of explanatory variable), the trend of the changes of the water level in the river (categorical, explanatory variable) and day of the season (continuous, explanatory variable). We computed GAM separately for each of three water levels defined by different periods. The penalized regression splines with the smoothing parameters selected by restricted maximum likelihood (REML) were used to fit the smooth function for the water level variable. The GAM was computed with the package "mgcv" in R (Wood 2020). We used adjusted $R^{2}$, the percentage of explained deviance and one-side ANOVA as a series of likelihood ratio tests to compare GAMs and select the best model describing the changes in the body mass of Great Snipes males. As we decided to use uncorrected body mass as an indicator of birds condition, we also checked if measurements of structural size of individual change with regard to the year and the water level. Since none of those relationships were significant, we did not include the linear measurements into the GAM models as a covariate (additional information is given in Online Resource 1).

\section{Results}

\section{Changes of the body mass within a year}

We found the decrease in the body mass of lekking males of Great Snipe over the breeding season according to Generalized Linear Model, with insignificant influence of a year as a cofactor (GLM, Wald's statistics $=14.75, p=0.01$; Fig. 1 ). In the first 3 days of May, the average body mass of birds was $156.5 \mathrm{~g}$ and by the end of the month, the body mass dropped to $152.2 \mathrm{~g}$. On average, the body mass of birds

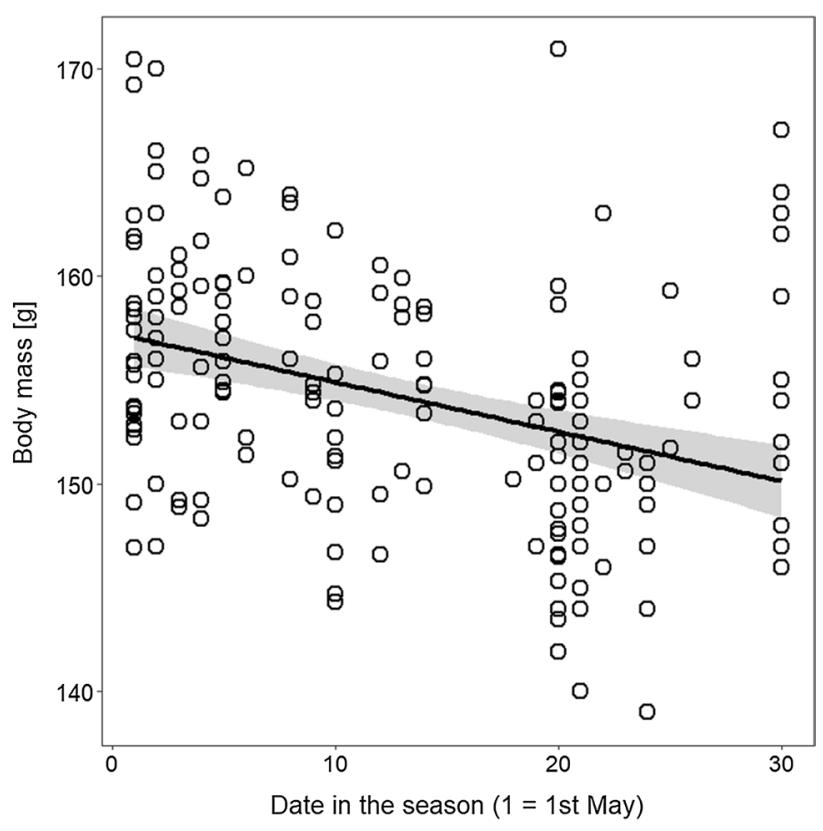

Fig. 1 Relationship between the body mass of lekking male Great Snipes and sampling date in the season. The black line represents a significant relationship estimated with the Generalized Linear Model (GLM, $p<0.05)$ and the grey area represents a 95\% confidence interval 
declined by approximately $3 \%$ over the whole month. Based on the regression function, during May lekking males of Great Snipe lose daily on average $0.15 \mathrm{~g}$ of the body mass.

\section{Influence of the water level in the Pripyat River on the body mass}

Among all variables incorporated into the proposed models, the date of the capture of an individual in the season had no significant influence on the body mass according to all nine computed Generalized Additive Models (Table 1). The water level and increasing trend in the water level had an effect on the body mass of birds, in contrast to the decreasing trend of water level, that did not influence this parameter (Table 1). Comparison of all nine GAMs showed significant differences (ANOVA, $F=14.67, p=0.003$ ), with only two GAMs being different from the rest of the proposed models: model 4 , with the body mass explained by the mean water level from 5 days before the day of the capture as a single predictor (Tukey's post hoc test, $p<0.05$ ) supported as the best model with the highest percentage of explained deviance and highest adjusted $R^{2}$ (Table 1 ). The second model shown to be different from the rest of proposed models was model 7 with the body mass explained by the mean water level from 14 days before the day of the capture, water level trend and date of the capture (Tukey's post hoc test, $p<0.05$ ), presented as the worst fitting model with lowest percentage of explained deviance and lowest adjusted $R^{2}$. The remaining seven models did not differ from each other. Hence, only the best fitting model number 4 (Table 1) was used for further analyses.

The body mass of male Great Snipes was relatively stable when the water level in the river ranged from 210 to $440 \mathrm{~cm}$ as shown by the smoothed, conditional local means of this parameter (Fig. 2). A higher level of water was related to an increase in body mass until birds obtained the highest score of body mass when the water level was high and reached approximately $490 \mathrm{~cm}$. Further increase in the water level was linked to the decrease in the body mass of lekking birds (Fig. 2).

Two opposing trends in the changes of the water level differently affected the body mass of male Great Snipes (Table 1). The decreasing trend in the water level did not influence the body mass of birds, whereas the increasing trend of changes in water level was linked to an increase in this parameter (Fig. 3). The increase of the body mass was observed until it had reached the maximum value for the available data set at the water level of $471 \mathrm{~cm}$.

Table 1 Parameters of different generalized additive models used to model the body mass (BM) of lekking male Great Snipes

\begin{tabular}{|c|c|c|c|c|c|c|c|c|c|c|c|c|}
\hline \multirow[t]{4}{*}{ No } & \multirow[t]{4}{*}{ Model } & \multicolumn{8}{|c|}{ Independent variables } & \multicolumn{3}{|c|}{ Model parameters } \\
\hline & & \multicolumn{2}{|c|}{ Water level } & \multicolumn{4}{|c|}{ Water trend } & \multirow{2}{*}{\multicolumn{2}{|c|}{ Day }} & \multirow[t]{3}{*}{ edf } & \multirow[t]{3}{*}{$R^{2}$ adj } & \multirow[t]{3}{*}{ Dev. exp } \\
\hline & & \multirow[b]{2}{*}{$p$} & \multirow[b]{2}{*}{$F$} & \multicolumn{2}{|c|}{ Increasing } & \multicolumn{2}{|c|}{ Decreasing } & & & & & \\
\hline & & & & $p$ & $t$ & $p$ & $t$ & $p$ & $t$ & & & \\
\hline & \multicolumn{12}{|c|}{ Water level measured on the day of the capture } \\
\hline 1 & $\mathrm{BM}=\mathrm{s}($ WaterL1 $)$ & 0.001 & 3.99 & - & & - & & - & & 6.06 & 0.163 & $19.8 \%$ \\
\hline 2 & $\mathrm{BM}=\mathrm{s}($ WaterL1 $)+$ Water $\mathrm{T}$ & 0.044 & 1.82 & 0.001 & 4.58 & ns & & - & & 1.26 & 0.145 & $16.4 \%$ \\
\hline 3 & $\mathrm{BM}=\mathrm{s}($ WaterL1 $)+$ Water $\mathrm{T}+$ Day & 0.027 & 1.73 & 0.001 & 2.53 & ns & & ns & & 1.49 & 0.152 & $17.8 \%$ \\
\hline & \multicolumn{12}{|c|}{ Water level averaged over 5 days preceding the day of the capture } \\
\hline 4 & $\mathrm{BM}=\mathrm{s}($ WaterL5 $)$ & 0.001 & 4.25 & - & & - & & - & & 3.38 & 0.182 & $21.2 \%$ \\
\hline 5 & $\mathrm{BM}=\mathrm{s}($ WaterL5 $)+$ Water $\mathrm{T}$ & 0.012 & 3.45 & 0.001 & 4.18 & ns & & - & & 3.39 & 0.176 & $20.6 \%$ \\
\hline 6 & $\mathrm{BM}=\mathrm{s}($ WaterL5 $)+$ WaterT + Day & 0.046 & 2.55 & 0.001 & 3.26 & ns & & ns & & 1.41 & 0.152 & $17.7 \%$ \\
\hline & \multicolumn{12}{|c|}{ Water level averaged over 14 days preceding the day of the capture } \\
\hline 7 & $\mathrm{BM}=\mathrm{s}($ WaterL14 $)$ & 0.004 & 3.53 & - & & - & & - & & 5.49 & 0.136 & $16.9 \%$ \\
\hline 8 & $\mathrm{BM}=\mathrm{s}($ WaterL14 $)+$ WaterT & 0.009 & 2.02 & 0.001 & 4.30 & ns & & - & & 6.05 & 0.170 & $20.4 \%$ \\
\hline 9 & $\mathrm{BM}=\mathrm{s}($ WaterL14 $)+$ Water $\mathrm{T}+$ Day & 0.043 & 1.79 & 0.002 & 3.19 & ns & & ns & & 1.79 & 0.156 & $18.4 \%$ \\
\hline
\end{tabular}

Effective degrees of freedom, adjusted $R^{2}$ and the percentage of deviance explained is given. $\mathrm{s}()$ indicates the smooth term, WaterL1-water level measured in the day of the capture, WaterL5-the water level averaged over 5 days preceding the day of the capture, WaterL14-the water level averaged over 14 days preceding the day of the capture, WaterT - trend in the water level, Day — day of the capture in the season, ns-statistically non-significant result, '-'-lack of given parameter in the model 


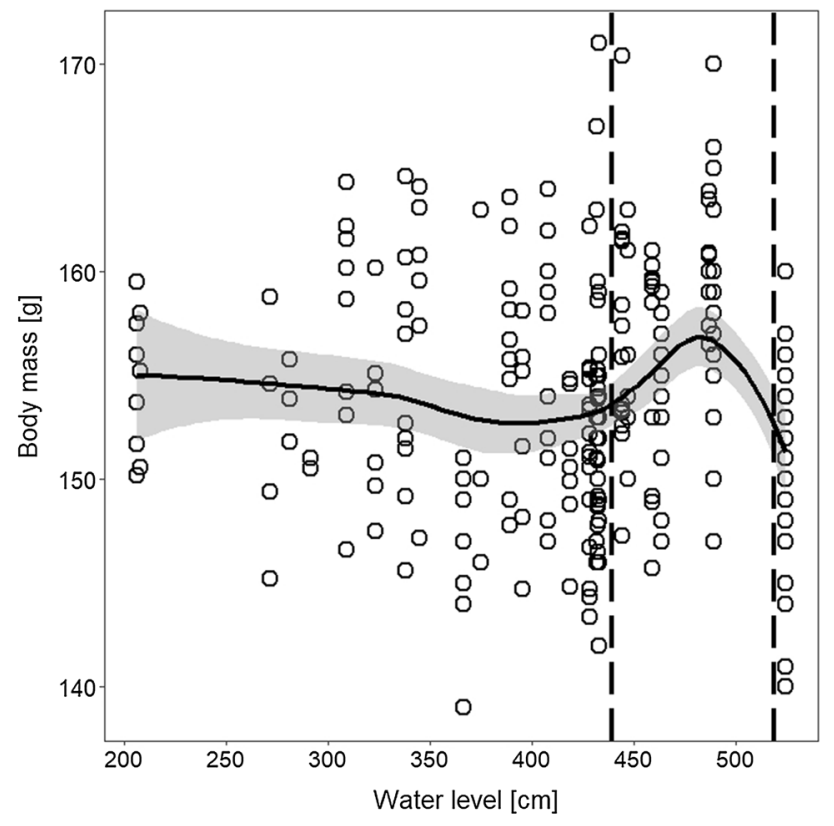

Fig. 2 Relationship between the body mass of lekking male Great Snipes and mean water level of Pripyat River from 5 days before the day of the birds' capture. The line represents smoothed conditional, local means along with the estimated $95 \%$ confidence intervals (grey area). The dashed lines indicates the water level at which the water enters the meadows and at which the meadows are totally flooded

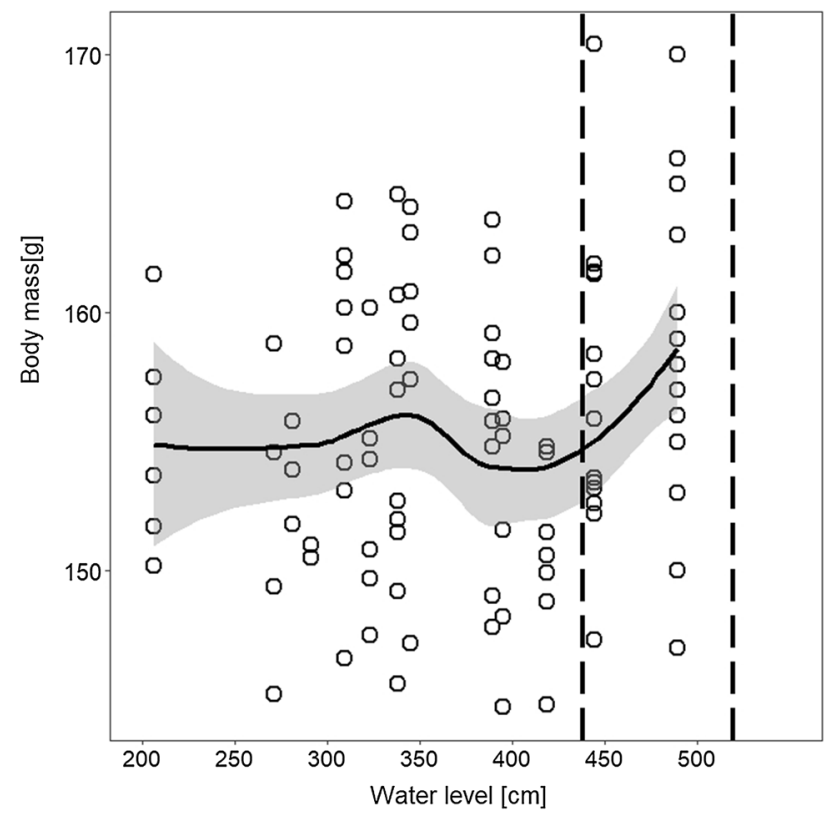

Fig. 3 Relationship between the body mass of lekking male Great Snipes and mean water level of Pripyat River from 5 days before the day of the birds' capture during the increasing trend of water level changes. The black line represents a significant relationship estimated with the smoothed conditional, local means and the grey shaded area represents a 95\% confidence interval. The dashed lines indicates the water level at which the water enters the meadows and at which the meadows are flooded

\section{Discussion}

Advertising display of males of lekking species is considered energetically costly, leading to loss of energetic resources over the mating season. Such decrease in body condition was commonly observed also in other lekking bird species such as Jackson's Widowbird Euplectes jacksoni (Andersson 1994), Black Grouse Tetrao tetrix (Hämäläinen et al. 2012; Lebigre et al. 2013), Sage Grouse Centrocercus urophasianus (Vehrencamp et al. 1989) and Great Bustard Otis tarda (Carranza and Hidalgo de Trucios 1993). The males' constant ability to regain the lost resources is determined by the abundance of feeding sites on the breeding area, but also might reflect the quality of a given male. The body condition of lekking Great Snipes' males decreased over the studied period. Similarly, Höglund et al. (1992) described the loss of the body mass during the course of May in displaying Great Snipes. However, this relationship was significant only according to Generalized Linear Model analysis and was significant in none of the parameterised Generalized Additive Models. We think that the lack of significance of this factor is caused by smaller sample size, as for Generalized Linear Model we used data from 20 years and for Generalized Additive Model we limited the data set to years when data on Pripyat water levels were available. It can be also explained by uneven sampling effort in different years, as in some seasons there was only one capture event or capture events were not distributed evenly over the studied period.

Changes in the water level on the breeding site influenced the body condition of lekking Great Snipe males in our study area. Davis et al. (2006) showed that the water level of the river was responsible for the water-table depth and the soil moisture of adjacent wet meadows, which influenced the abundance of the earthworms in the top layer of the soil. It was hypothesised that hydrological changes in this region do not only influence the soli fauna itself, but as these invertebrates play an important part in the food chain of this ecosystem, it is likely that animals, such as birds are also influenced as they rely on the abundance and accessibility of these invertebrates. The relative stability of the body condition of lekking Great Snipes was observed for most of the range of studied water levels, indicating that the lower water levels (approximately from 220 to $420 \mathrm{~cm}$ ) did not affect their body condition significantly. In these hydrological conditions, the water table is low and probably does not considerably change earthworms' accessibility for Great Snipes. The remaining, unflooded top layer of the soil is an area of a great thickness, that cannot be totally penetrated with the bill, as Great Snipes have access to maximally $6 \mathrm{~cm}$ depth of the top layer of the soil. The stability of the body condition of male Great Snipes at a 
large range of water levels of approximately two meters, might be an indicator of the high richness of the feeding sites in the proximity of the leks.

With the further rise of the water level beyond approximately $420 \mathrm{~cm}$ the body condition of males increased to the point of reaching the highest value at the water level of approximately $490 \mathrm{~cm}$. This pattern was also observed in the trend of water level changes with the rise of the water level in the river. It appears that these hydrological conditions were the most favourable for male Great Snipes, allowing for an increase in the individual's body condition despite the high energetic costs of ongoing lekking. In such hydrological circumstances, the remaining unflooded soil layer is thin, and earthworms are bound to occupy it in great densities. The Great Snipe uses the tactile foraging strategy, probing the soil and mud with a bill in search for prey (Cramp and Simmons 1983), and prefers feeding sites with high soil penetrability (Korniluk et al. 2020). This parameter relies on the hydrological conditions of the meadow, as higher soil moisture can cause the top layer of the soil to become easier to penetrate (Armstrong 2000; Milsom et al. 2002). Therefore, the rise of the water level could not only improve the availability of prey by increasing the density of earthworms at the top layer of the soil, but also change the ground properties towards easier probing. In these circumstances, potentially more area becomes suitable feeding sites for Great Snipes, which might increase their body condition by lowering the need for more distant flights in search for a better feeding place as well as reducing the competition between individuals.

At very high water levels, when meadows are gradually flooded, we observed a decline of the body condition of lekking Great Snipes. At these very high water levels, the feeding conditions probably start to deteriorate, as the earthworms tend to leave the flooded soil (Ausden et al. 2001). There is a strong dependence of the length of wading species' legs and the depth of the water they prefer to forage, with short-legged species preferring shallower water (Baker 1979; Ntiamoa-Baidu et al. 1998). The bill length of Great Snipe males is considerably long, but their legs are relatively short. Therefore, the flooded area gradually stops being attractive for birds, as more possible feeding sites are submerged under water, which is too deep for their relatively short legs, despite Great Snipes' ability to reach the earthworms in the flooded meadow with their long bill. Therefore, individuals face limited access to food resources and the necessity of compensating for the worsening feeding condition, possibly by longer flights in search of higher positioned parts of the meadow. Such flights and increased competition between birds in a limited area of the feeding sites increase the energy demand, which causes an observed decline in the body condition of male Great Snipes. It is also possible that at the high water level states, with rising water level trends, the increase of body condition of male Great Snipes can be caused by the birds accumulating body energetic storages, as a preparation for the threat of worsening feeding conditions due to the approaching flooding event. During such an event, the accumulated energy stores can ensure males' undisturbed mating activity and attendance to the lek, that for many lekking birds was proved to be a factor related to the higher number of copulations and therefore higher mating success (Fiske et al. 1994; Lesku et al. 2012; Jiguet and Bretagnolle 2014). Similar phenomenon was also described in wintering Dunlins Calidris alpina during deteriorating thermal and foraging conditions (Kelly et al. 2002).

Changes in the water level of the river may have an indirect impact on the body condition of lekking Great Snipe males by determining the richness of feeding sites. However, it is worth mentioning that the presented models incorporating studied hydrological conditions are characterised by relatively weak statistical support. Therefore, we think that there is a number of other unstudied factors that influence the body condition of displaying Great Snipes, that would require further studies. In other lekking species of birds, it has been proved that more attractive males had higher body condition and that they bear greater energetic costs of producing the attractive secondary sexual trait as well as displaying and maintaining their position at the lek, compared to less attractive or nonbreeding individuals (Andersson 1994; Lebigre et al. 2013; Vehrencamp et al. 1989). For Great Snipes such detailed studies on individual costs of lekking have not yet been investigated, but we think that similarly to other lekking species, individual's changes in the body condition depend on energetic investment in the displaying of a male. Long lasting unfavourable weather conditions may result in decrease of body condition and lowering the lek attendance of lekking males (Vehrencamp et al. 1989; Fremgen et al. 2018). In our study, we were unable to incorporate other environmental factors that could alter the body condition such as ambient temperature, precipitation and wind conditions that can cause variation in body condition of individuals (Gardner et al. 2018). Nonetheless, according to our findings the right hydrological management of grasslands in river valleys is especially important not only for Great Snipes, but possibly also for other earthworm-feeding species and should allow the natural regime of water in the river with its water level fluctuations in spring. Unfortunately, only $37 \%$ of long rivers of the world remain free flowing, with dams, reservoirs, water extraction, and sediment trapping disrupting the natural flow of the rest of them (Grill et al. 2019). Those practices, along with diverting wet meadows of river valleys into intensively used agricultural land with excessive fertilization and drainage diches created to lower the level of groundwater, are the main reasons for losing the suitable breeding habitat for wader species of such ecosystems, among other negative effects causing the 
deterioration of the feeding conditions. Therefore, recently the wader species habituating wet meadows of river valleys suffered a decline in number (Vickery et al. 2001; Verhulst et al. 2007; Onrust and Piersma 2017; Onrust et al. 2019).

Supplementary Information The online version contains supplementary material available at https://doi.org/10.1007/s10336-022-01966-5.

Acknowledgements We would like to thank all volunteers who worked at the Turov Ringing Station and assisted during the fieldwork, in particular D. Zhuravliov, A. Zyatikov, I. Bogdanovich, A. Usau, V. Khursanau, A. Khalandach and I. Kashpei. We thank A. Ożarowska and N. Sheeran for proofreading the manuscript and English language corrections. We would also like to thank T. Piersma and anonymous Reviewer 2 for all the valuable comments and advice. The experiments comply with the current laws of Belarus. Bird ringing and data collection were conducted by experienced, qualified ringers with valid licenses and the permission of the Belarusian ringing authority.

Author contributions MW, PP, WM, NK carried out the fieldwork. MW and ZM statistically analysed the data with MW taking a lead in writing the manuscript.

Funding This study was possible thanks to funding from the University of Gdańsk (UGrants-start 1220/116/2021), the National Academy of Sciences of Belarus and APB BirdLife Belarus.

Data availability The data are available upon reasonable request to the corresponding author.

Code availability Not applicable.

\section{Declarations}

Conflict of interest The authors declare there is no conflict of interest.

Ethical approval All conducted procedures were in accordance with Belarussian law.

Consent to participate Not applicable.

Consent for publication Not applicable.

Open Access This article is licensed under a Creative Commons Attribution 4.0 International License, which permits use, sharing, adaptation, distribution and reproduction in any medium or format, as long as you give appropriate credit to the original author(s) and the source, provide a link to the Creative Commons licence, and indicate if changes were made. The images or other third party material in this article are included in the article's Creative Commons licence, unless indicated otherwise in a credit line to the material. If material is not included in the article's Creative Commons licence and your intended use is not permitted by statutory regulation or exceeds the permitted use, you will need to obtain permission directly from the copyright holder. To view a copy of this licence, visit http://creativecommons.org/licenses/by/4.0/.

\section{References}

Andersson S (1994) Costs of sexual advertising in the lekking Jackson's Widowbird. Condor 96:1-10. https://doi.org/10.2307/1369058
Armstrong AC (2000) DITCH: a model to simulate field conditions in response to ditch levels managed for environmental aims. Agric Ecosyst Environ 77:179-192. https://doi.org/10.1016/S01678809(99)00082-1

Atkinson PW, Buckingham D, Morris AJ (2004) What factors determine where invertebrate-feeding birds forage in dry agricultural grasslands? Ibis 146:99-107. https://doi.org/10.1111/j.1474919X.2004.00346.X

Ausden M, Sutherland WJ, James R (2001) The effects of flooding lowland wet grassland on soil macroinvertebrate prey of breeding wading birds. Appl Soil Ecol 38:320-338. https://doi.org/10. 1046/j.1365-2664.2001.00600.x

Baker MC (1979) Morphological correlates of habitat selection in a community of shorebirds (Charadriiformes). Oikos 33:121-126. https://doi.org/10.2307/3544520

Berry EC, Jordan D (2001) Temperature and soil moisture content effects on the growth of Lumbricus terrestris (Oligochaeta: Lumbricidae) under laboratory conditions. Soil Biol Biochem 33:133-136. https://doi.org/10.1016/S0038-0717(00)00112-7

Bogaart P, van der Loo M, Pannekoek J (2020) rtrim: trends and indices for monitoring data. $\mathrm{R}$ package version 2.1.1. https:// cran.r-project.org/web/packages/rtrim/index.html

Bohlen PJ, Edwards CA (1995) Biology and ecology of earthworms. Springer, Netherlands, Heidelberg

Busse P, Meissner W (2015) Bird ringing station manual. De Gruyter Open Ltd, Warsaw

Carranza J, Hidalgo de Trucios SJ (1993) Condition-dependence and sex traits in the male Great Bustard. Ethology 94:187-200. https://doi.org/10.1111/j.1439-0310.1993.tb00559.x

Coulson J, Coulson BA (2008) Lesser Black-backed Gulls Larus fuscus nesting in an inland urban colony: the importance of earthworms (Lumbricidae) in their diet. Bird Study 55:297-303. https://doi.org/10.1080/00063650809461535

Cramp S, Simmons KEL (1983) The birds of the western Palearctic, vol III. Oxford Univ. Press, Oxford

Davis CA, Austin JA, Buhl DA (2006) Factors influencing soil invertebrate communities in riparian grasslands of the Central Platte River floodplain. Wetlands 26:438-454

Debayle EJM, Devort M, Klaassen RHG, Lindström Å (2017) Great Snipes in sub-Saharan Africa: seasonal patterns of abundance, moult and body mass in relation to age and sex. Wader Study 124:186-196. https://doi.org/10.18194/ws.00084

Ekblom R, Sæther SM, Grahn M, Fiske P, Kålås JA, Höglund J (2004) Major histocompatibility complex variation and mate choice in a lekking bird, the great snipe (Gallinago media). Mol Ecol 13:3821-3828. https://doi.org/10.1111/j.1365-294X. 2004.02361.x

Fiske P, Kålås JA, Sæther SA (1994) Correlates of male mating success in the lekking great snipe (Gallinago media): results from a four-year. Behav Ecol 5:210-218

Fiske P, Rintamäki T, Karvonen E (1998) Mating success in lekking males: a meta-analysis. Behav Ecol 9:328-338. https://doi.org/ 10.1093/beheco/9.4.328

Fremgen A, Hansen C, Rumble M, Gamo S, Millspaugh J (2018) Weather conditions and date influence male Sage Grouse attendance rates at leks. Ibis 161:1. https://doi.org/10.1111/ibi.12598

Gardner JL, Rowley E, de Rebeira P, de Rebeira A, Brouwer L (2018) Associations between changing climate and body condition over decades in two southern hemisphere passerine birds. Clim Chang Responses 5:2. https://doi.org/10.1186/ s40665-018-0038-y

Grant WC (1955) Studies on moisture relationships in earthworms. Ecol 36:400-407. https://doi.org/10.2307/1929574

Green RE, Hirons GJM, Cresswell BH (1990) Foraging habitats of female Common Snipe Gallinago gallinago during the incubation period. J Appl Ecol 27:325-335. https://doi.org/10.2307/2403589 
Grill G, Lehner B, Thieme M, Geenen B, Tickner B, Antonelli B, Babu D, Borrelli P, Cheng L, Crochetiere H, Ehalt Macedo H, Filgueiras R, Goichot M, Higgins J, Hogan Z, Lip B, McClain ME, Meng J, Mulligan M, Nilsson C, Olden JD, Opperman JJ, Petry P, Reidy Liermann C, Sáenz L, Salinas-Rodrígue S (2019) Mapping the world's free-flowing rivers. Nature 569:215-221. https://doi.org/ 10.1038/s41586-019-1111-9

Hämäläinen A, Alatalo RV, Lebigre C, Siitari H, Soulsbury CD (2012) Fighting behaviour as a correlate of male mating success in black grouse Tetrao tetrix. Behav Ecol Sociobiol 66:1577-1586. https:// doi.org/10.1007/s00265-012-1411-7

Hamer GL, Heske EJ, Brawn JD, Brown PW (2006) Migrant shorebird predation on benthic invertebrates along the Illinois River, Illinois. Wilson J Ornithol 118:152-163. https://doi.org/10.1676/05-024.1

Hastie T, Tibshirani R (1986) Generalized additive models. Stat Sci 1:297-318. https://doi.org/10.1214/ss/1177013604

Höglund J, Alatalo RV (1995) Leks. Princeton University Press, Princeton

Höglund J, Lundberg A (1987) Sexual selection in a monomorphic lek-breeding bird: correlates of male mating success in the great snipe Gallinago media. Behav Ecol Sociobiol 21:211-216. https:// doi.org/10.1007/BF00292501

Höglund J, Kålås JA, Lofaldli L (1990) Sexual dimorphism in the lekking Great Snipe. Ornis Scand 21:1-6. https://doi.org/10.2307/ 3676372

Höglund J, Kålås JA, Fiske P (1992) The costs of secondary sexual characters (Gallinago media) in the lekking great snipe. Behav Ecol Sociobiol 30:309-315. https://doi.org/10.1007/BF00170596

Jiguet F, Bretagnolle V (2014) Sexy males and choosy females on exploded leks: correlates of male attractiveness in the Little Bustard. Behav Process 103:246-255. https://doi.org/10.1016/j. beproc.2014.01.008

Jiménez JJ, Decaëns T (2000) Vertical distribution of earthworms in grassland soils of the Colombian llanos. Biol Fertil Soils 32:463473. https://doi.org/10.1007/s003740000277

Kålås JA (2004) International Single species action plan for the conservation of the Great Snipe. Tech Ser. No. 5. UNEP/AEWA Secretariat, Bonn

Kålås JA, Fiske P, Höglund J (1997) Food supply and breeding occurrences: The West European population of the lekking Great Snipe Gallinago media (Latham, 1787) (Aves). J Biogeogr 24:213-221. https://doi.org/10.1046/j.1365-2699.1997.00093.x

Kelly JP, Warnock N, Page GW, Weathers W (2002) Effects of weather on daily body mass regulation in wintering dunlin. J Exp Biol 205:109-120. https://doi.org/10.1242/jeb.205.1.109

Korniluk M, Białomyzy P, Grygoruk G, Kozub Ł, Sielezniew M, Świętochowski P, Tumiel T, Wereszczuk M, Chylarecki P (2020) Habitat selection of foraging male Great Snipes on floodplain meadows: importance of proximity to the lek, vegetation cover and bare ground. Ibis 163:486-506. https://doi.org/10.1111/ibi. 12898

Labocha MK, Hayes JP (2012) Morphometric indices of body condition in birds: a review. J Ornithol 153:1-22. https://doi.org/10. 1007/s10336-011-0706-1

Labocha MK, Schutz H, Hayes JP (2014) Which body condition index is best? Oikos 123:111-119. https://doi.org/10.1111/j.1600-0706. 2013.00755.x

Lebigre C, Alatalo RV, Siitari H (2013) Physiological costs enforce the honesty of lek display in the black grouse (Tetrao tetrix). Oecologia 172:983-992. https://doi.org/10.1007/s00442-012-2548-9

Lemnell PA (1978) Social behaviour of the Great Snipe Capella media at the arena display. Ornis Scand 9:146-163. https://doi.org/10. 2307/3675876

Løfaldli L, Kålås JA, Fiske P (1992) Habitat selection and diet of Great Snipe Gallinago media during breeding. Ibis 134:35-43. https:// doi.org/10.1111/j.1474-919X.1992.tb07227.x
Macdonald DW (1983) Predation on earthworms by terrestrial vertebrates. In: Satchell J (ed) Earthworm ecology. From darwin to vermiculture. Springer, Dordrecht

Mather JG, Christensen O (1988) Surface movements of earthworms in agricultural land. Pedobiol 32:399-405

McCullagh P, Nelder JA (1989) Generalized linear models. Champman and Hall London, New York

Meissner W, Karlionova N, Pinchuk P (2011) Fueling rates by spring-staging Ruffs Philomachus pugnax in southern Belarus. Ardea 99:147-155. https://doi.org/10.5253/078.099.0204

Milsom TP, Hart JD, Parkin WK, Peel S (2002) Management of coastal grazing marshes for breeding waders: the importance of surface topography and wetness. Biol Conserv 103:199-207. https://doi.org/10.1016/S0006-3207(01)00122-7

Morales MB, Alonso JC, Martín C, Martín E, Alonso J (2003) Male sexual display and attractiveness in the great bustard Otis tarda: the role of body condition. J Ethol 21:51-56. https://doi.org/10. 1007/s10164-002-0076-5

Ntiamoa-Baidu Y, Piersma T, Wiersma P, Poot M, Battley P, Gordon C (1998) Water depth selection, daily deeding routines and diet of waterbirds in coastal lagoons in Ghana. Ibis 140:89-103. https://doi.org/10.1111/j.1474-919X.1998.tb04545.x

Onrust J, Piersma T (2017) The hungry worm feeds the bird. Ardea 105:153-161. https://doi.org/10.5253/arde.v105i2.a4

Onrust J, Wymenga E, Piersma T, Olff H (2019) Earthworm activity and availability for meadow birds is restricted in intensively managed grasslands. J Appl Ecol 56:1333-1342. https://doi. org/10.1111/1365-2664.13356

Peig J, Green AJ (2009) New perspectives for estimating body condition from mass/length data: the scaled mass index as an alternative method. Oiks 118:1883-1891. https://doi.org/10.1111/j. 1600-0706.2009.17643.x

Pinchuk PV, Karlionova NV (2011) Influence of climate factors on phenology of spring migration of waders in the south of Belarus. Branta 14:12-25

Pinchuk PV, Karlionova NV, Bogdanovich IA, Luchik EA, Meissner W (2016) Age and seasonal differences in biometrics of Dunlin (Calidris alpina) migrating in spring through the Pripyat river floodplain, southern Belarus. Zool Zhurnal 95:327-334. https:// doi.org/10.1134/S1062359016090156

Plum NM, Filser J (2005) Floods and drought: response of earthworms and potworms (Oligochaeta: Lumbricidae, Enchytraeidae) to hydrological extremes in wet grassland. Pedobiologia 49:443-453. https://doi.org/10.1016/j.pedobi.2005.05.004

Rawlins MA, Ye H, Yang D, Shiklomanov A, McDonald KC (2009) Divergence in seasonal hydrology across northern Eurasia: emerging trends and water cycle linkages. J Geophys Res 114:D18119. https://doi.org/10.1029/2009JD011747

Rhymer CM, Robinson RA, Smart J, Whittingham MJ (2010) Can ecosystem services be integrated with conservation? A case study of breeding waders on grassland. Ibis 152:698-712. https://doi.org/10.1111/j.1474-919X.2010.01049.x

Roots BI (1956) The water relations of earthworms II: resistance to desiccation and immersion, and behaviour when submerged and when allowed a choice of environment. J Exp Biol 33:29-44

Rundgren S (1975) Vertical distribution of lumbricids in southern Sweden. Oikos 26:299-306. https://doi.org/10.2307/3543500

Ryder T, Tori W, Blake J, Loiselle B, Parker P (2010) Mate choice for genetic quality: a test of the heterozygosity and compatibility hypotheses in a lek-breeding bird. Behav Ecol 21:203-210. https://doi.org/10.1093/beheco/arp176

Sæther SA, Fiske P, Kålås J, Gjul JM (2000) Females of the lekking great snipe do not prefer males with whiter tails. Anim Behav 59:273-280. https://doi.org/10.1006/anbe.1999.1301

Sardà-Palomera F, Puigcerver M, Vinyoles D, Rodrígueaz-Teijeiro JD (2011) Exploring male and female preferences, male body 
condition, and pair bonds in the evolution of male sexual aggregation: the case of the Common Quail (Coturnix coturnix). Can J Zool 89:325-333. https://doi.org/10.1139/z11-005

Tockner K, Stanford JA (2002) Riverine flood plains: present state and future trends. Environ Conserv 29:308-330. https://doi.org/10. 1017/S037689290200022X

Vehrencamp SL, Bradbury JW, Gibson RM (1989) The energetic cost of display in male sage grouse. Anim Behav 38:885-896. https:// doi.org/10.1016/S0003-3472(89)80120-4

Verhulst J, Kleijn D, Berendse F (2007) Direct and indirect effects of the most widely implemented Dutch agri-environment schemes on breeding waders. J Appl Ecol 44:70-80. https://doi.org/10.1111/j. 1365-2664.2006.01238.x

Vickery JA, Tallowin JR, Fever RE, Asteraki EJ, Atkinson PW, Feller RJ, Brown VK (2001) The management of lowland neutral grasslands in Britain: effects of agricultural practices on birds and their food resources. J Appl Ecol 38:647-664. https://doi.org/10.1046/j. 1365-2664.2001.00626.x

Ward JV, Tockner K, Schiemer F (1999) Biodiversity of floodplain ecosystems: ecotones and connectivity. Regul Rivers: Res Manag 15:125-139. https://doi.org/10.1002/(SICI)10991646(199901/06) 15:1/3\%3C125::AID-RRR523\%3E3.0.CO;\%202-E

Wever L, Lysyk T, Clapperton M (2001) The influence of soil moisture and temperature on the survival, aestivation, growth and development of juvenile Aporrectodea tuberculata (Eisen) (Lumbricidae). Pedobiologia 133:121-133. https://doi.org/10.1078/ 0031-4056-00074

Wood SN (2020) Package 'mgcv': mixed GAM computation vehicle with automatic smoothness estimation. $\mathrm{R}$ package version 1.8-33. https://cran.r-project.org/web/packages/mgcv/index.html

Yang C, Wang J, Fang Y, Sun Y-H (2013) Is sexual ornamentation an honest signal of male quality in the Chinese Grouse (Tetrastes sewerzowii)? PLoS ONE 8:e82972. https://doi.org/10.1371/journ al.pone. 0082972

Zorn MI, van Gestel CAM, Eijsackers H (2005) Species-specific earthworm population responses in relation to flooding dynamics in a Dutch floodplain soil. Pedobiologia 49:189-198. https://doi.org/ 10.1016/j.pedobi.2004.08.004

Zorn MI, van Gestel CAM, Morriën E, Wagenaar M, Eijsacker H (2008) Flooding responses of three earthworm species, Allolobophora chlorotica, Aporrectodea caliginosa and Lumbricus rubellus, in a laboratory-controlled environment. Soil Biol Biochem 40:587-593. https://doi.org/10.1016/j.soilbio.2007.06.028

Publisher's Note Springer Nature remains neutral with regard to jurisdictional claims in published maps and institutional affiliations. 